\title{
ArcheoSciences
}

Revue d'archéométrie

33 (suppl.) | 2009

Mémoire du sol, espace des hommes

\section{New data from magnetic survey of Ptolemais}

\author{
Krzysztof Misiewicz and Wiesław Małkowski
}

\section{(2) OpenEdition}

\section{Journals}

Electronic version

URL: https://journals.openedition.org/archeosciences/1402

DOI: 10.4000/archeosciences. 1402

ISBN: 978-2-7535-1599-4

ISSN: 2104-3728

Publisher

Presses universitaires de Rennes

Printed version

Date of publication: 30 October 2009

Number of pages: 117-120

ISBN: 978-2-7535-0943-6

ISSN: 1960-1360

Electronic reference

Krzysztof Misiewicz and Wiesław Małkowski, "New data from magnetic survey of Ptolemais",

ArcheoSciences [Online], 33 (suppl.) | 2009, Online since 30 October 2011, connection on 01 February

2022. URL: http://journals.openedition.org/archeosciences/1402 ; DOI: https://doi.org/10.4000/

archeosciences. 1402 


\title{
New data from magnetic survey of Ptolemais
}

\author{
Krzysztof Misiewicz* and Wiesław MaŁKowski*
}

Key words: Non-invasive survey, Archaeological geophysics, Magnetic survey, Ptolemais, Libya.

During non-invasive surveys carried out at the site Ptolemais since 2002 we have collected, processed and interpreted many different kinds of data: Quickbird-2 satellite imagery, oblique air photographs made with the use of KAP system in various years, seasons and lighting condition; fieldwalking survey, surveys with several geophysical methods (Misiewicz, 2005; Bogacki, 2008).

Last two seasons the efficiency of magnetic prospection was tested with the aim to prepare the optimal method for surveying all the site covering a surface of ca. 200 hectares accessible for archaeological investigations (Fig. 1).

For that purpose the whole central area of the site had been measured with a PMP-8 G proton precision magnetometer, Geometrics G-858 cesium magnetometer, a single sensor Geoscan FM 256 and a Bartington Grad 601-2 single axis, dual sensor fluxgate gradiometer in the same grid and under the same surface conditions (Fig.2). The lower sensors of all instruments were guided ca. $30 \mathrm{~cm}$ above a ground. All observation of the changes of magnetic field have been carried out in one direction - from south to north in all surveyed area. Spacing of the lines was set to $0,5 \mathrm{~m}$ and sampling rate to $25 \mathrm{~cm}$. Later in data processing and visualization the raster was interpolated to $0.25 \times 0.25 \mathrm{~cm}$.

Obtained results clearly show once more that both single and multi-probe fluxgate magnetometers are the ideal instruments for detecting near surface structures with a high magnetization contrast (Tabbagh, 2003). At Ptolemais this was the case for the remains of buildings laying at central part of the town - Greek Agora/ Roman Forum (Fig. 3) but the sensitivity of the instruments working in the verti- cal gradient configuration were not suitable enough for the detection of the deeper buried structures(Bogacki, 2007).

A PMP-8 G proton precision magnetometer seemed to be the most suitable instrument for archaeological prospection in the conditions of multi-layer site. Exact localization of magnetic anomalies caused by architectural remains deposited even on big depth (2-4 meter beneath a surface) was possible independent of the sensors configuration (vertical and horizontal gradient measurements, correction by a base station and non-compensated duo-sensor configuration have been tried in the field). Additionally, it was possible to use a second magnetometer - PMP7 in a fixed station nearby a surveyed area (base station) to monitor the magnetic field temporal variations. Working with a sampling rate the instrument has been used to synchronize base and walking magnetometers clocks. After fixing a reference time, the temporal variations measured by the base station unit has been removed from the data acquired by the survey unit. That way the residual magnetic field represents the spatial variations component only have been recorded and all features creating magnetic anomalies could be localize very precisely. However, not to fast measuring speed, inadequate sensitivity (forcing the operations described above) and heavy weight of the sensors being the main disadvantages for field operations enabled to use this instrument for surveying all the site.

A G-858 cesium-vapor magnetometer measuring all component of magnetic field allowed to localize archaeological features even with bigger precision and additionally was much faster in all operation in the field that was important in the situation when due to the surface irregularities it was

*Institute of Archaeology University of Warsaw. (geomis@iaepan.edu.pl), (wmalkowski@uw.edu.pl) 


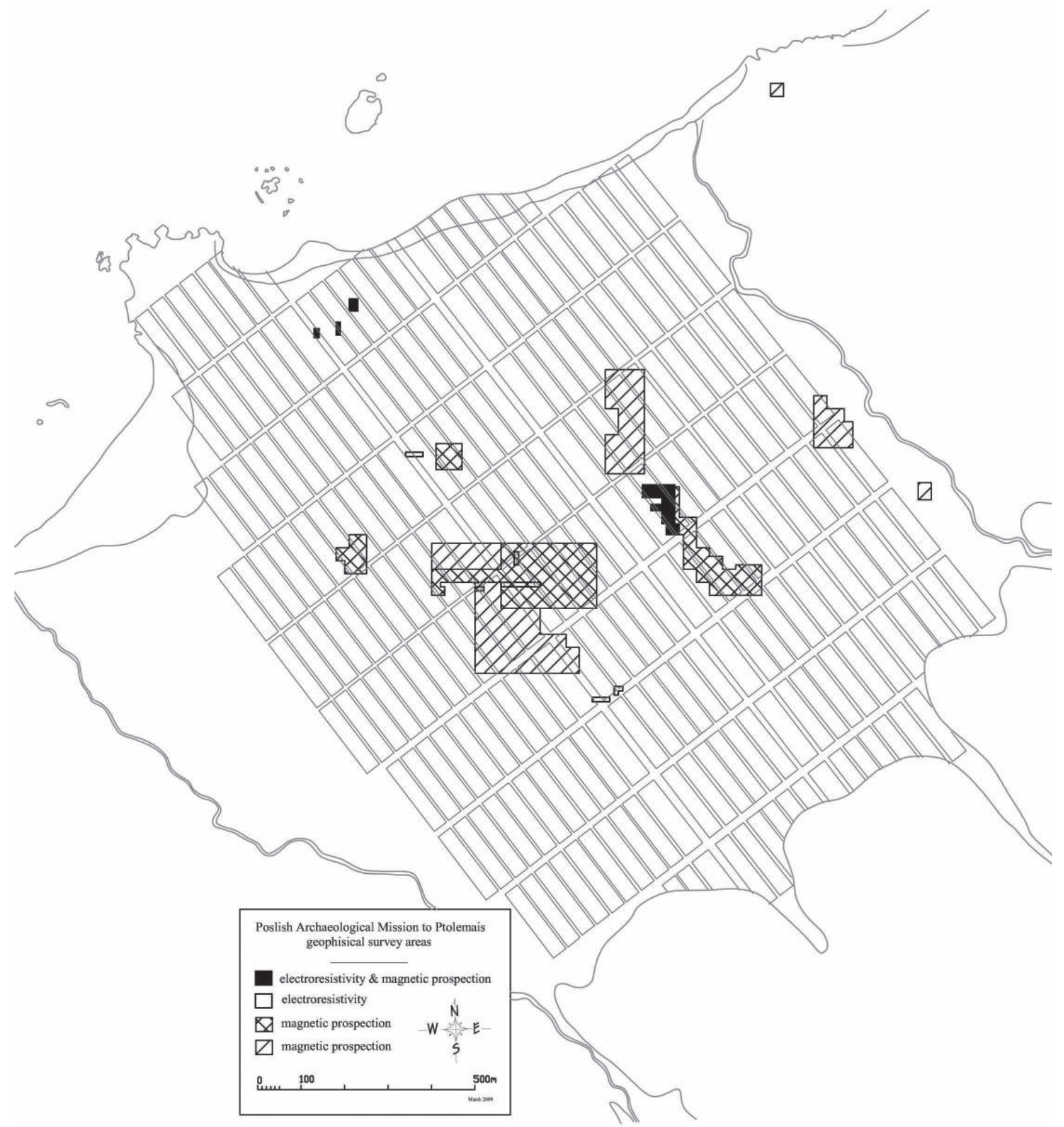

Figure 1: Ptolemais. Localization of geophysical surveys.

practically impossible to use a highly automated systems on a chart with GPS localization. The instrument used for the test measurements was a Geometrics G-858 G cesium gradiometer with 2 sensors. The sensors were configured horizontally with a distance of $0,5 \mathrm{~m}$ and vertically 0.3 and
1,3 $\mathrm{m}$ above a ground. At normal walking speed the sample rate on the profile was in the range of $10 \mathrm{~cm}$ and it was possible to survey over 2 hectares a day with $0,5 \mathrm{~m}$ lines spacing. The presence of archaeological remains was detected with the use of the instruments in both horizontal and ver- 


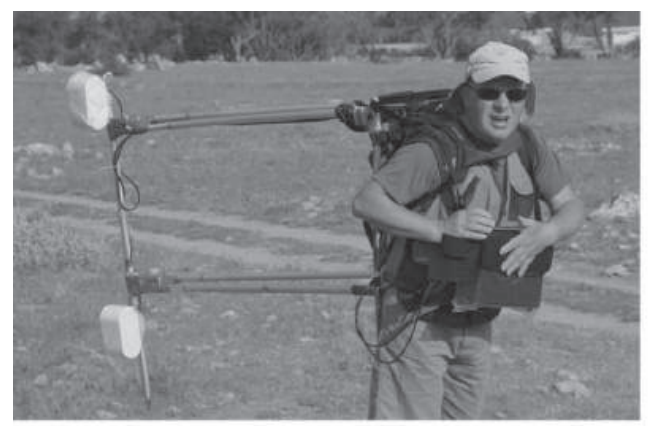

A

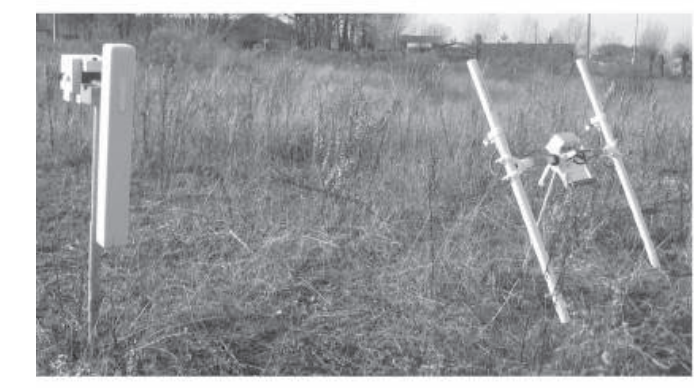

C

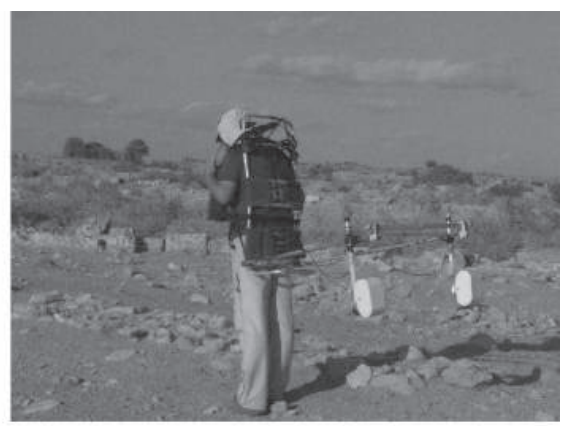

B

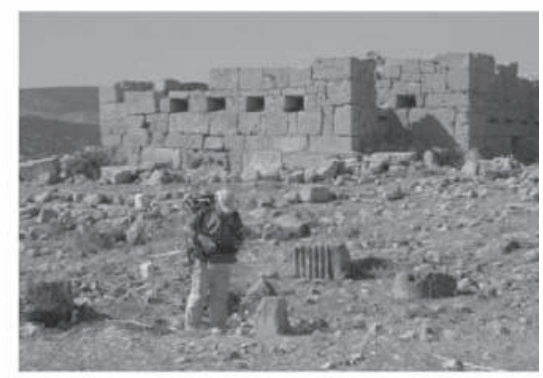

D

Figure 2: Ptolemais. Surveys with different types of magnetometers. A, D - proton magnetometer. PMP-8 G in vertical gradient mode, $\mathrm{B}$ - proton magnetometer PMP-8 G in horizontal gradient mode, C - Geoscan FM 256 and Bartington Grad 601-2 fluxgates gradiometers. 
tical probes configuration. However, in test area most of the features detected lied close to the surface and it was impossible to check the efficiency of the instrument in detecting deeper buried structures.

Having over 200 hectares to survey it was necessary to prepare a system of localization of measuring points with the use of GPS. Our main aim was to synchronize the magnetometer internal clock with the GPS signal in order to precisely attribute a spatial datum to the magnetic field values. GPS boards tested in the field were a 12 channel South S82 and a Topcon GR3 RTK base - rover system. Both instruments working with the use of $2 \mathrm{~W} / 5 \mathrm{~W} 451 \mathrm{~Hz}$ frequency radio system enabled to localize measuring points with a resolution of less than $2 \mathrm{~cm}$ in static mode and $5 \mathrm{~cm}$ in RTK measurements.

New data from the tests allow to generate maps for over 30 hectares inside city walls and to complete information on city grid and course of the streets. Hypothetical reconstruction of city plan prepared by Polish Archaeological Mission (works on it have been carried out since 2002), was confirmed by insulae borders visible in magnetic maps as linear narrow anomalies. Features in the places within insulae, where remains of buildings are preserved allow to reconstruct possible plan of the part of town laying close to central square- agora/forum localized at 2007. Interesting complex of anomalies are registered also outside of the central part of the town and seems to be caused by the remains of monumental buildings (temple?). The presence of Corinthian capitals, visible on the surface here seems to confirm the last hypothesis.

Only ca. 30 from over 200 hectares have been surveyed since 2005. New magnetic data help to plane detailed surveys not only inside city walls and to continue non-invasive investigations in more reasonable way.

\section{References}

BogaCki, M., MaŁkowski, W., МiкоскI, T. and Misiewicz, K., 2007. Multimethodological approach to the study of ancient city planning: the case of Ptolemais in Cyrenaica, Libya, Archaeological Prospection. Studijne Zvesti Archaeologickeho Ustavu Slovenskej Academie Vied, 41: 117-119.

Bogacki, M., MaŁkowski, W. and Misiewicz, K., 2008. Kite Aerial Photography (KAP) as a tool for completing GIS models. Ptolemais (Libya) case study, Remote Sensing for Archaeology and Cultural Heritage Management. In Lasaponara, R, Masini, N. (dir.), Rome, 329-333.

Misiewicz, K. Jaworski, P., MaŁкоwski, W., Мiкоскi, T. and MuszYŃsKa, M., 2005. Non-destructive surveys of an ancient city of Ptolemais in Cyrenaica (Libya). In Piro, S., (dir.). 6th International Conference on Archaeological Prospection, Roma, 195-197.

Taвbagh, J., 2003. Total Field Magnetic Prospection: Are Vertical Gradiometer Measurements Preferable to Single Sensor Survey? Archaeological Prospection, 11: 75-82. 